\title{
Fertility-Preserving Treatment Options in Patients with Malignant Hematological Diseases
}

\section{Malin Hematolojik Hastalıklarda Fertilite Koruyucu Tedavi Seçenekleri}

\author{
Mert Küçük ${ }^{1}$, Ali Zahit Bolaman², İrfan Yavaşoğlu², Gürhan Kadıköylü ${ }^{2}$ \\ ${ }^{1}$ Adnan Menderes University, School of Medicine, Department of Obstetrics and Gynecology, Aydin, Turkey \\ ${ }^{2}$ Adnan Menderes University, School of Medicine, Department of Internal Medicine, Division of Hematology, Aydin, Turkey
}

\begin{abstract}
The number of patients of reproductive age diagnosed with various malignant hematological diseases increases every year. These patients undergo chemotherapy, radiotherapy, and various other treatments that may have gonadotoxic effects. The life expectancy of these patients is increasing rapidly due to the variety of treatment options. As such, an increasing number of patients—as well as their parents and spouses—express their concerns about the patient's fertility post treatment. In the present review it was aimed to provide an overview of current fertility-preserving treatment options and the future of fertility preservation.
\end{abstract}

Key Words: Fertility preservation, Malignant hematological diseases, Ovarian tissue cryopreservation, Embryo cryopreservation

Özet

Her yıl üreme çağında çeşitli malin hematolojik hastalıklara yakalanan hasta sayısı artmaktadır. Bu hastalar gonadotoksik etkileri olabilen kemoterapi, radyoterapi ve çeşitli tedaviler almaktadırlar. Hastaların beklenen yaşam süreleri ise çeşitli tedavi seçeneklerinin yardımı ile hızla artmaktadır. Bu nedenle giderek artan sayıda hasta, ebeveynleri ve hastaların eşleri tedavi sonrası hastanın fertilite potansiyeli üzerine endişelerini ifade etmektedirler. Bu derlemede güncel fertilite koruyucu tedavi seçenekleri ve fertilite prezervasyonunun geleceği konusunda bilgi vermek amaçlandı.

Anahtar Sözcükler: Fertilite prezervasyonu, Malin hematolojik hastalıklar, Over doku kryoprezervasyonu, Embriyo kryoprezervasyonu

\section{Introduction}

It is well known that some treatment options used in patients with malignant hematological diseases negatively affect fertility. The negative effects of various treatments on fertility, the steadily increasing number of cures available, and improvement in 5-year life expectancy have all served to increase the importance of patient quality of life
(QoL). Among patient QoL issues is the desire of patients to become parents post treatment [1].

Schover et al. reported that $76 \%$ of childless young cancer survivors reported wanting to become a parent and that they were concerned about the effects of cancer treatment on their fertility [1]. Fertility preservation in cancer patients is becoming a more frequent issue in oncologi-

Address for Correspondence: Mert KÜÇÜK, M.D.,

Adnan Menderes Üniversitesi, Tıp Fakültesi, Kadın Hastalıkları ve Doğum Anabilim Dalı, Aydın, Turkey

Phone: +90 2564441256 E-mail: dr.mertkucuk@gmail.com

Received/Geliş tarihi : October 13, 2011

Accepted/Kabul tarihi : December 20, 2011 
cal practice. The American Society of Clinical Oncology (ASCO) recently published a clinical guidebook that encourages healthcare professionals to inform patients about and discuss fertility-preserving treatment options [2]. The American Society of Reproductive Medicine (ASRM) Ethics Committee has also expressed its concern for this issue [3].

Today, the fertility-preserving treatment options most commonly offered to patients are cryopreservation of sperm and embryos [2-4]. Pregnancy has also been made possible via oocyte and ovarian tissue cryopreservation [5]. Other fertility preservation methods are still in the experimental stage. This review aimed to provide an overview of currently used fertility-preserving treatment options, those still undergoing experimentation, and a look into the potential future of fertility preservation.

In 1948 it was reported that nitrogen mustard had a toxic effect on the testes [6]. Since then, the adverse effects on reproduction of many treatment procedures have become known.

Chemotherapy can lead to amenorrhea or a reduction in the ovarian reserve [7]. Alkylating agents-particularly cyclophosphamide-are known gonadotoxic agents [7]. Oktay et al. reported that patients treated with alkylating agents had fewer primordial follicles in their ovaries than those that were not treated with these agents [8]. Generally as the dose and duration of treatment increase, so do the negative effects [9]. Younger patients have a larger pool of primordial follicles and are more able to tolerate the chemotherapy. Ovarian follicles are more sensitive to chemotherapy during the proliferative phase of the menstrual cycle $[10,11]$. Pelvic radiotherapy negatively affects the reproductive system, causing degeneration of primary and primordial follicles [12].

In fact, fertility preservation should be guided by two principles: 1. Use of treatments that are the least gonadotoxic as possible; 2 . Use of fertility-preserving treatment options when gonadotoxicity cannot be avoided [13].

The majority of patients with acute lymphoblastic leukemia (ALL), acute myeloid leukemia (AML), Hodgkin's lymphoma (HL), and nonHodgkin's lymphoma (NHL) have reproductive potential prior to treatment, making treatment-related infertility an important issue. Hematopoietic stem cell transplantation (HSCT) is frequently included in the treatment plan of patients with hematologic diseases. During HSCT gonadotoxic agents known to have a very negative effect on future fertility are used [14]. In fact, the potential effect of each hematological malignancy and each treatment protocol on future fertility is unique. What follows is a brief explanation of important malignant hematological disorders and HSCT and fertility preservation options [14]. It is important to note that gonadotoxic treatments and/or HSCT are used not only in cases of malignancy, but in patients with precancerous and benign diseases [5].

\section{Lymphomas}

Among patients with HL and NHL, 5-year survival has increased markedly, approaching approximately greater than $80 \%$. The success of current treatment modalities for malignant hematologic diseases has facilitated an increase in clinicians' ability to focus on such problems as post-treatment infertility [13]. Semen analysis must be performed in all male patients with lymphomas prior to treatment. The quality of semen is lower in patients with HL and NHL than in healthy male controls. Among male patients diagnosed with HL, 21\% and 49\% had azoospermia, and moderate or mild semen abnormalities, respectively [14]. The exact cause of these abnormalities has not yet been elucidated. These disorders in HL may be related to fever or pro-inflammatory cytokines, such as interleukin 1 (IL1), IL6, tumor necrosis factor- $\alpha$, and soluble IL receptors 2 and 6 [14]

A relationship has not been observed between disease stage and quality of semen in HL [15-17]. The folliclestimulating hormone level in male patients was suggested to be a marker of male fertility [18] and inhibin B was suggested as an indirect marker of male fertility [19]. Low levels of inhibin B were associated with impaired spermatogenesis in children and adults receiving chemotherapy [20]. Anti-Müllerian hormone was reported to be an important predictor and marker of gonadal function in women that underwent chemotherapy for HL [21].

The most common cause of gonadal dysfunction in patients with HL is gonadotoxic chemotherapy [15]. Alkylating chemotherapeutic agents, such as procarbazine and/ or cyclophosphamide, cause prolonged azoospermia in 90\%-100\% of men and premature ovarian failure (POF) in $5 \%-25 \%$ of younger women under 30 years old; however, the risks are low with radiotherapy alone if pelvic radiation or chemotherapy with alkylating agents is not given [22]. Previously the MOPP (mechlorethamine, vincristine, procarbazine, prednisolone), COPP (cyclophosphamide, vincristine, procarbazine, prednisolone), and MOPP-ABV (alternating cycles of mechlorethamine, vincristine, procarbazine, prednisolone, and doxorubicin, bleomycin, vinblastin, and dacarbazine) regimens were frequently 
administered, whereas ABVD (doxorubicin, bleomycin, vinblastin, and dacarbazine) and BEACOPP (bleomycin, etoposide, doxorubicin, cyclophosphamide, vincristine, procarbazine, and prednisolone) chemotherapy regimens are currently more popular.

The MOPP, COPP, and MOPP-ABV chemotherapy regimens are more toxic to the gonads than the other mentioned regimens and may cause secondary leukemia. As such, they are not commonly used to treat HL, as they may have greater gonadotoxic effects in HL patients in whom gonadal damage was evident during the pre-treatment period [22]. The ABVD regimen is a non-alkylating regimen that is less gonadotoxic compared to regimens including alkylating agents. Among those treated with the ABVD regimen, only $33 \%$ of male patients experienced transient azoospermia, and $8 \%$ of female patients developed POF. In comparison to regimens containing alkylating agents, such as BEACOPP, these rates were significantly lower [18]. The gonadotoxic effects of second-line HL chemotherapy regimens, including DHAP (dexamethasone, cytarabine, and cisplatin), ICE (ifosfamide, carboplatin, and etoposide), and MINE (mesna, ifosfamide, mitoxantrone, etoposide), remain unknown [22]. NHL patients often receive the $\mathrm{CHOP}$ regimen or $\mathrm{CHOP}$-based regimens; among such patients, the observed rate of gonadal toxicity is low, both in men and women [23].

\section{Leukemias and HSCT}

Fertility preservation has become an important issue among patients with acute leukemias due to the increase in the success of various chemotherapy protocols. Male leukemia patients had lower pre-treatment semen parameters than healthy controls [24]. Standard chemotherapy regimens used for the treatment of AML and ALL have little toxic effect on reproductive potential [25]. Treatmentrelated infertility in leukemia patients is generally related to HSCT [26].

HSCT, along with its associated gonadotoxic conditioning regimens, has been successfully used for the treatment of both lymphoma and leukemia. HSCT may be performed as autologous or allogeneic transplantation. The gonadotoxic effect of HSCT in leukemia patients is related to whether or not a myeloablative or non-myeloablative conditioning regimen is administered, and whether or not total body irradiation (TBI) is used as a conditioning regimen prior to HSCT [27]. Myeloablative pre-transplant conditioning regimens include alkylating agents and/or TBI [28]. Both alkylating agents and TBI are associated with marked germ cell damage and infertility [29]. Azo- ospermia is more frequently encountered in patients that have undergone allogeneic HSCT and received myeloablative conditioning regimens. Additionally, spermatogenesis is frequently impaired in this group of patients; however, spermatogenesis sometimes improves 9-10 years following gonadotoxic therapy [30].

Patients treated with TBI followed by HSCT have a high risk of gonadotoxicity [31]. The gonadotoxic effect of TBI increases in particular when combined with cyclophosphamide [32]. POF is more common when TBI is used for preconditioning. The incidence of POF is lower in cases treated with non-myeloablative conditioning regimens and autologous transplantation [33]. Although rare, recovery of ovarian function can occur years after HSCT in cases in which POF is observed [34]. Radiation can also lead to hypothalamic amenorrhea [35]. One study reported that $68 \%$ of patients undergoing radiotherapy of both ovaries developed ovarian failure [36]. Another adverse effect of radiotherapy is a reduction in blood flow to the uterus and a decrease in uterine volume [37]. Pelvic irradiation has been associated with adverse obstetric and neonatal outcomes-among them, spontaneous abortion, low birth weight, and placental anomalies [38-40]. Pelvic irradiation has also been associated with placenta accreta and percreta, as well as uterine rupture [39-44]. Moreover, patients that undergo allogenic HSCT or irradiation, or patients that develop graft-versus-host disease (GVHD) are reported to be at risk for implantation problems [45]. In addition to gonadal damage, these patients may develop vaginal and cervical stenosis, resulting in deterioration of sexual function, with dyspareunia and reproductive failure, or difficult childbirth [45].

Gonadal damage is expected to be extensive in the following patients: patients aged $\geq 30$ years at the time of HSCT, especially those that receive chemotherapy with alkylating agents before HSCT; patients that develop GVHD; patients with a predisposition for infiltration of the gonads; male patients; patients that receive TBI; patients treated with TBI that have undergone allogeneic HSCT; post-pubertal patients [27]. Patients scheduled for HSCT should receive fertility counseling during the pre- and post transplant periods [27].

\section{Fertility Preservation Options}

\section{Embryo Cryopreservation}

The ASRM Ethics Committee reported that embryo cryopreservation is the most successful method available today for fertility preservation [3]. Embryo cryopreservation consists of the following 4 steps: 1 . Controlled ovarian 
hyperstimulation and induction of multifollicular growth; 2. Retrieval of follicles from the ovaries, generally under transvaginal ultrasound guidance; 3 . In vitro fertilization with the partner's sperm or fertilization via intra-cytoplasmic sperm injection (ICSI); 4. Cryopreservation of the resultant embryos.

Embryo cryopreservation can be performed via traditional slow-freezing or a rapid freezing method referred to as vitrification. Embryo survival after thawing is expected to be around $90 \%$ with the vitrification method, versus $75 \%$ with the slow freezing method $[46,47]$.

In some of the following cases embryo cryopreservation is unsuitable or difficult to accomplish; 1 . The method is not suitable for prepubertal females; 2 . In Turkey the patient must be married. Cryopreservation with donor sperm is not legal in Turkey; 3. Supraphysiological estrogen levels during ovarian stimulation are regarded by some clinicians as prohibitive, particularly in patients with hormone-dependent cancers [48]; the use of letrozole, however, is recommended during controlled ovarian hyperstimulation in patients with hormone-dependent cancers [49]; 4. Patients generally need a few weeks to a few months for ovarian stimulation for embryo cryopreservation which sometimes may not be preffered [50].

\section{Sperm Cryopreservation}

Sperm cryopreservation is a fertility preservation method with a high rate of successful outcomes and is easy to implement. The recommendation is that sperm should be collected three times, each after $48 \mathrm{~h}$ of abstinence [51]. In cases in which the underlying pathology is HL, testicular cancer, or leukemia the sperm count and/or quality may be low [52]. With the help of supplementary reproduction techniques and, in particular ICSI, success is possible when even a limited number of sperm are frozen and then thawed [53]. Sperm cryopreservation is possible even if chemotherapy or radiotherapy has already been initiated [54]; however, for maintaining DNA integrity in cases of a low sperm count, it is recommended that sperm be collected before such treatment begins.

Alternatives to obtaining sperm via masturbation include penile vibrator stimulation, testicular aspiration, testicular extraction, electroejaculation [55]. Testicular tissue cryopreservation is another alternative fertility preservation option. Testicular stem cell transplantation and transplantation of frozen-and-thawed testicular cells back to the testes after various gonadotoxic treatments are currently under investigation [13].

\section{Oocyte Cryopreservation}

Oocyte cryopreservation is a method in which-similar to embryo cryopreservation-the ovaries are subjected to controlled hyperstimulation, and then the oocytes are retrieved via a minor surgical procedure [56]. This method is unsuitable for pediatric patients. This method has some advantages and disadvantages in comparison with embryo cryopreservation: 1. Oocyte cryopreservation can be used in women without a partner. 2. Oocytes are much more sensitive to freezing and thawing procedures than embryos [57], and as such the success rate of this method is limited; therefore, ASRM still regards this method as experimental [3]; 3. Following freezing and thawing, thickening of the zona pellucida reduces the chances of fertilization of the oocyte [58]. Although ASRM regards this method as experimental, the technology is rapidly advancing [59]. The increase in oocyte survival rates after freezing and thawing following vitrification is promising, but the rate remains low [60]. In short, oocyte cryopreservation is still in the development stage and research is ongoing; nonetheless, results obtained to date show that that technique has great promise.

\section{Ovarian Tissue Cryopreservation}

Ovarian tissue cryopreservation consists of the following: 1. Surgical_and usually-laparoscopic removal of part of the ovarian tissue; 2. Cryopreservation of the removed ovarian tissue; 3 . Thawing and processing of the ovarian tissue when the decision to do so is made, after which time the tissue is subjected to heterotopic or orthotopic implantation; in cases of heterotopic implantation the frontal abdominal wall [61] or the forearm [62] is used, whereas orthotopic sites employed are the ovarian fossa and the pelvic peritoneum. Transplantation can also be made to the cortex of the residual ovary $[63,64]$.

Ovarian tissue cryopreservation appears to be the only choice for prepubertal females and in particular, for postpubertal patients in whom treatment cannot be postponed, even for a short time (cases in which there is no time for ovarian stimulation either for embryo or oocyte cryopreservation) [65]. Another advantage of ovarian tissue cryopreservation is its applicability during any stage of the menstrual cycle. The resistance of primordial follicles to cryotoxicity compared to that of mature oocytes is another advantage of the method [66]

The disadvantages of ovarian tissue cryopreservation are as follows: 1 . It requires surgery; 2 . It is associated with the risk of thrombosis and hemorrhaging; 3. Although primordial follicles are more resistant, as there 
is no blood flow at the initial ischemia $66 \%$ of oocytes lose their viability [67]; 4. There is a theoretical risk, although low, that with this method malignant cells might find their way back into the patient's tissues. The ovaries are seldom the site of metastasis, but leukemia, neuroblastoma, and breast cancers have been known to metastasize to the ovaries $[68,69]$. This is particularly important in cases of BRCA1- and BRCA2-positive mutations [70], in which the removed ovarian tissue must be evaluated histopathologically; 5 . The rate of success and clinician experience with this method are quite limited; to date, very few live births have been reported as an outcome of this method [71,72]. In short, ovarian tissue cryopreservation is a new technique with which clinicians have limited experience, and outcome data are in short supply.

\section{Ovarian Transposition, and Intensity-Modulated Radiation Therapy (IMRT) and Gonadal Shielding}

The aim of ovarian transposition is to move the ovaries of patients with HL, neuroblastoma, Wilms tumor, and other similar conditions to a location in the body that is outside the radiation field [71]. The procedure includes the following: 1. Surgical transposition of the ovaries to an area outside of the field of radiation; 2. Following radiotherapy, the ovaries are returned to their original location. The success rate for this procedure is reported to be $16 \%$ 90\% [73]. Ovarian transposition can be performed prior to irradiation via laparotomy or laparoscopy [74]. Application of metal clips to the ovaries during the procedure is useful in guiding subsequent X-ray localization. Additionally, a sample of ovarian tissue can be excised during the procedure for cryopreservation. The risks associated with ovarian transposition are postoperative chronic pelvic pain and pelvic adhesions. Although rare, it should also be kept in mind that the ovaries may migrate back to their former locations [75]. Moreover, damage to the ovaries resulting from the combination of chemotherapy and radiotherapy cannot be prevented with this method.

IMRT is a relatively new radiation technique that facilitates delivery of radiation to multiple targets while sparing adjacent tissues. This method is used to minimize the distribution of radiation and the harmful effects of radiation on the ovaries and uterus [76].

Shielding the uterus and ovaries to as great a degree as possible during radiotherapy or dividing the TBI doses may be of benefit to avoid gonadotoxicity [65].

\section{Ovarian Suppression with a Gonadotropin- Releasing Hormone (GnRH) Analog}

It is known that the ovaries in prepubertal females are more resistant to chemotherapy compared to postpubertal females. GnRH analog treatment is thought to convert the hormonal environment in post-pubertal females to the prepubertal environment, so that the ovaries become more resistant to the toxic effects of chemotherapy. A meta-analysis reported that the use of GnRH analogs prior to chemotherapy was an effective method [77]. Nonetheless, to date the effectiveness of GnRH analog treatment for fertility preservation remains inconclusive [8] and additional large-scale randomized studies are necessary.

\section{Xenotransplantation}

Xenotransplantation - transplantation of human ovarian tissue into other species-is in the experimental stage $[78,79]$. Xenotransplantation has been used successfully to create functional oocytes [80]. As xenotransplantation is still in the experimental stage, the procedure raises issues of safety and ethics. The transfer of non-human DNA or contamination with viruses may turn out to be risks associated this procedure [81].

\section{Stem Cells}

Stem cells are able to differentiate into diverse specialized cell types. Research continues on methods of cloning germ cells from adult somatic cells and the creation of new differentiated cells from stem cells $[82,83]$.

\section{Current Legislation in Turkey}

According to Turkish regulations concerning assisted reproductive treatment methods and assisted reproductive treatment centers, partners that undergo such treatment may only receive their own reproductive cells. It is illegal to make use of a donor in any way-to harvest an embryo from a donor, transfer an embryo from one assisted reproductive treatment candidate to another via use of eggs or sperm harvested from a candidate, and to use or implant embryos in assisted reproductive treatment candidates that have been harvested from non-candidates [84].

When embryos have been retrieved, these can be cryopreserved with the consent of both partners. If an embryo has been preserved over one year, each year the couple must confirm their desire to continue the preservation by submitting a signed petition. Upon the consent of both partners, in the event of the death of one of the partners or a legally established divorce, or at the end of the determined period, a record is kept by a commission to be appointed by the health directorate of the city and the embryos are destroyed [84].

It is legal for both men and women to preserve reproductive cells and gonad tissue before undergoing treat- 
ment that may damage gonad cells, such as chemotherapy or radiotherapy. To maintain the security of the materials, reproductive cells and gonad tissue are preserved together with a DNA analysis of the donor. In the event that preservation exceeds one year individuals must apply to the authorities with a signed petition confirming the desire to continue the preservation of the tissues/cells. Anytime an individual fails to renew the protocol, or upon his/her request, or in the event of death, a record is kept by a commission to be appointed by the health directorate of the city and the cryopreserved reproductive cells and gonad tissues are destroyed [84]. Reproductive cells and gonad tissues, as well as frozen embryos, may be preserved for a maximum of five years; preservation exceeding five years is subject to the approval of the Ministry of Health [84].

\section{Fertility Preservation Risks and Ethical Considerations}

Although fertility preservation treatment has undergone significant advancement and continues to generate great interest, and despite the fact that many oncology patients and their families currently seek such treatment, the ethical issues surrounding its use remain unresolved. At the same time, promising new developments and methods of fertility preservation (e.g. xenotransplantation) complicate the ethics of such treatment. In addition, as each individual and culture has unique psychosocial, cultural, and religious sensitivities and realities, the ethical issues associated with fertility preserving treatment vary accordingly.

An important ethical issue concerns non-adult patients and the informed consent process; in particular, is it ethical for such decisions to be made by the parents of minors. As such, scientific authorities have stressed the importance of ensuring that children and adolescents are involved in the informed consent process to a degree that is age appropriate [85]. When children or adolescents are concerned, besides age, having the capacity to understand the situation in which the individual is in is more important not age but when participating in the fertility preservation process. It is, however, not always easy to determine whether such capacity exists. A family's decision about a minor's future reproductive choice can, for example, result in the rejection of cryopreservation, which in later years becomes an ethical issue if the adult child now wished to become a parent. Additionally, parents that opt for gamete cryopreservation for their child can have the cells destroyed before the patient has reached legal age. Still, another ethical issue concerns the future of cryopreserved embryos or gametes in the event a patient dies, i.e. a healthy partner wants to become pregnant with a preserved embryo after her partner has died.

An important ethical consideration is the degree to which patients and their families are informed about experimental fertility preservation options. The information provided to patients should specify that the process is experimental and objective data provided should include information on success rates. Incorrectly raising the hopes of patients and their families when experimental methods are being tested will inevitably bring about many problems. In addition, all oncology patients must be informed about fertility preservation options and their written informed consent must be obtained prior to such treatment. If patients or their legal guardians refuse fertility preservation, clinicians must document their choice. When a legal issue arises and patients claim that they were not informed about fertility preservation options, or if they admit that they were, but claim to have actually asked for one of the options, in order to resolve a possible dispute, there needs to be a written consent that was signed by the patient and/or the legal guardian before the treatment for cancer. Another issue is the matter of who should obtain a patient's informed consent-the patient's attending physician or the reproductive endocrinologist.

It is a possibility that malignant cells may be reintroduced when tissue is re-transplanted during the ovarian tissue cryopreservation procedure [86]. The time needed for oocyte or embryo cryopreservation and sometimes the clinician's feeling pressed enough to act quickly to start the treatment for cancer or the necessity to do so can also be problematic [87]. The risk of transferring non-human DNA or viruses to humans when employing xenotransplantation must always be a consideration [81], as well as the potential hazards of the interaction of human and animal DNA [88]. Another important ethical issue concerns problems that might arise if a patient becomes pregnant following fertility preservation treatment and then has oncological relapse during the pregnancy [87].

Although there are no studies in this area, it can be assumed that clinicians' awareness of the matter of fertility preservation may be lacking. The clinicians report that presentation of oncology patients to fertility preservation clinics is not a frequent occurrence. As such, we think that these methods are either underestimated or undervalued by such patients. Hematologists should continue to search objectively for the underlying problems and the reasons for this probable underestimation. 


\section{Conclusion}

Sperm and embryo cryopreservation are fertility preservation methods proven to be successful. Oocyte cryopreservation and ovarian tissue cryopreservation have also resulted in successful births. Although xenotransplantation, stem cell utilization, and other experimental methods are still under development, they have potential for future success.

\section{Conflict of Interest Statement}

The authors of this paper have no conflicts of interest, including specific financial interests, relationships, and/ or affiliations relevant to the subject matter or materials included.

\section{References}

1. Schover LR, Rybicki LA, Martin BA, Bringelsen KA. Having children after cancer. A pilot survey of survivors' attitudes and experiences. Cancer 1999; 86: 697-709

2. Lee SJ, Schover LR, Partridge AH, Patrizio P, Wallace WH, Hagerty K, Beck LN, Brennan LV, Oktay K. American Society of Clinical Oncology: American Society of Clinical Oncology recommendations on fertility preservation in cancer patients. J Clin Oncol 2006; 24: 2917-2931

3. Ethics Committee of the American Society for Reproductive Medicine: Fertility preservation and reproduction in cancer patients. Fertil Steril 2005; 83: 1622-1628

4. The Practice Committee of the American Society of Reproductive Medicine and the Practice Committee of the Society for Assisted Reproductive Technology. Ovarian tissue and oocyte cryopreservation. Fertil Steril 2006; 86: $142-147$

5. Oktem O, Oktay K. Preservation of menstrual function in adolescent and young females. Ann N Y Acad Sci 2008; 1135: 237-243

6. Spitz S. The histological effects of nitrogen mustards on human tumors and tissues. Cancer 1948; 1 (3): 383-398

7. Meirow D, Nugent D. The effects of radiotherapy and chemotherapy on female reproduction. Hum Reprod Update 2001; 7: 535-543

8. Oktay K, Sönmezer M, Oktem O, Fox K, Emons G, Bang H. Absence of conclusive evidence for the safety and efficacy of gonadotropin-releasing hormone analogue treatment in protecting against chemotherapy-induced gonadal injury. Oncologist 2007; 12 (9): 1055-1066

9. Reyno LM, Levine MN, Skingley P, Arnold A, Abu Zahra H. Chemotherapy induced amenorrhea in a randomized trial of adjuvant chemotherapy duration in breast cancer. Eur J Cancer 1992; 29A (1): 21-23
10. Byrne J, Fears TR, Gail MH, Pee D, Connelly RR, Austin DF, Holmes GF, Holmes FF, Latourette HB, Meigs JW. Early menopause in long-term survivors of cancer during adolescence. Am J Obstet Gynecol 1992; 166 (3): 788-793

11. Larsen EC, Müller J, Schmiegelow K, Rechnitzer C, Andersen AN. Reduced ovarian function in long-term survivors of radiation- and chemotherapy-treated childhood cancer. J Clin Endocrinol Metab 2003; 88 (11): 5307-5314

12. Lee CJ, Park HH, Do BR, Yoon Y, Kim JK. Natural and radiation-induced degeneration of primordial and primary follicles in mouse ovary. Anim Reprod Sci 2000; 59 (1-2): 109-117

13. van der Kaaij MA, van Echten-Arends J, Simons AH, KluinNelemans HC. Fertility preservation after chemotherapy for Hodgkin lymphoma. Hematol Oncol 2010; 28 (4): 168-179

14. Rueffer U, Breuer K, Josting A, Lathan B, Sieber M, Manzke $\mathrm{O}$, Grotenhermen FJ, Tesch H, Bredenfeld H, Koch P, Nisters-Backes H, Wolf J, Engert A, Diehl V. Male gonadal dysfunction in patients with Hodgkin's disease prior to treatment. Ann Oncol 2001; 12 (9): 1307-1311

15. Viviani S, Ragni G, Santoro A, Perotti L, Caccamo E, Negretti E, Valagussa P, Bonadonna G. Testicular dysfunction in Hodgkin's disease before and after treatment. Eur J Cancer 1991; 27 (11): 1389-1392

16. Shekarriz M, Tolentino MV Jr, Ayzman I, Lee JC, Thomas AJ Jr, Agarwal A. Cryopreservation and semen quality in patients with Hodgkin's disease. Cancer 1995; 75 (11): 2732-2736

17. Hallak J, Mahran AM, Agarwal A. Characteristics of cryopreserved semen from men with lymphoma. J Assist Reprod Genet 2000; 17 (10): 591-594

18. van der Kaaij MA, Heutte N, Le Stang N, Raemaekers JM, Simons AH, Carde P, Noordijk EM, Fermé C, Thomas J, Eghbali H, Kluin-Nelemans HC, Henry-Amar M. European Organisation for Research and Treatment of Cancer: EORTC Lymphoma Group; Groupe d'Etude des Lymphomes de l'Adulte. Gonadal function in males after chemotherapy for early-stage Hodgkin's lymphoma treated in four subsequent trials by the European Organisation for Research and Treatment of Cancer: EORTC Lymphoma Group and the Groupe d'Etude des Lymphomes de l'Adulte. J Clin Oncol 2007; 25 (19): 2825-2832

19. Mabeck LM, Jensen MS, Toft G, Thulstrup M, Andersson M, Jensen TK, Giwercman A, Olsen J, Bonde JP. Fecundability according to male serum inhibin B--a prospective study among first pregnancy planners. Hum Reprod 2005; 20 (10): 2909-2915

20. van Beek RD, Smit M, van den Heuvel-Eibrink MM, de Jong FH, Hakvoort-Cammel FG, van den Bos C, van den Berg H, Weber RF, Pieters R, de Muinck Keizer-Schrama $\mathrm{SM}$. Inhibin B is superior to FSH as a serum marker for spermatogenesis in men treated for Hodgkin's lymphoma with chemotherapy during childhood. Hum Reprod 2007; 22 (12): 3215-3222 
21. van Beek RD, van den Heuvel-Eibrink MM, Laven JS, de Jong FH, Themmen AP, Hakvoort-Cammel FG, van den Bos C, van den Berg H, Pieters R, de Muinck Keizer-Schrama $\mathrm{SM}$. Anti-Mullerian hormone is a sensitive serum marker for gonadal function in women treated for Hodgkin's lymphoma during childhood. J Clin Endocrinol Metab 2007; 92 (10): 3869-3874

22. Harel S, Ferme C, Poirot C. Management of fertility in patients treated for Hodgkin lymphoma. Haematologica 2011; 96 (11): 1692-1699

23. Elis A, Tevet A, Yerushalmi R, Blickstein D, Bairy O, Dann EJ, Blumenfeld Z, Abraham A, Manor Y, Shpilberg O, Lishner M. Fertility status among women treated for aggressive nonHodgkin's lymphoma. Leuk Lymphoma 2006; 47 (4): 623627

24. Hallak J, Kolettis PN, Sekhon VS, Thomas AJ Jr, Agarwal A. Cryopreservation of sperm from patients with leukemia: Is it worth the effort? Cancer 1999; 85 (9): 1973-1978

25. Jahnukainen K, Heikkinen R, Henriksson M, Cooper TG, Puukko-Viertomies LR, Mäkitie O. Semen quality and fertility in adult long-term survivors of childhood acute lymphoblastic leukemia. Fertil Steril 2011; 96 (4): 837-842

26. Watson M, Wheatley K, Harrison GA, Zittoun R, Gray RG, Goldstone AH, Burnett AK. Severe adverse impact on sexual functioning and fertility of bone marrow transplantation, either allogeneic or autologous, compared with consolidation chemotherapy alone: Analysis of the MRC AML 10 trial. Cancer 1999; 86 (7): 1231-1239

27. Chatterjee R, Kottaridis PD. Treatment of gonadal damage in recipients of allogeneic or autologous transplantation for haematological malignancies. Bone Marrow Transplant 2002; 30 (10): 629-635

28. Chatterjee R, Mills W, Katz M, McGarrigle HH, Goldstone AH. Germ cell failure and Leydig cell insufficiency in postpubertal males after autologous bone marrow transplantation with BEAM for lymphoma. Bone Marrow Transplant 1994; 13 (5): 519-522

29. Kreuser ED, Hetzel WD, Heit W, Hoelzer D, Kurrle E, Xiros N, Heimpel H. Reproductive and endocrine gonadal functions in adults following multidrug chemotherapy for acute lymphoblastic or undifferentiated leukemia. J Clin Oncol 1988; 6 (4): 588-595

30. Anserini P, Chiodi S, Spinelli S, Costa M, Conte N, Copello F, Bacigalupo A. Semen analysis following allogeneic bone marrow transplantation. Additional data for evidence-based counselling. Bone Marrow Transplant 2002; 30 (7): $447-$ 451

31. Sklar C. Growth and endocrine disturbances after bone marrow transplantation in childhood. Acta Paediatr Suppl 1995; 411: 57-61
32. Sanders JE, Hawley J, Levy W, Gooley T, Buckner CD, Deeg HJ, Doney K, Storb R, Sullivan K, Witherspoon R, Appelbaum FR. Pregnancies following high-dose cyclophosphamide with or without high-dose busulfan or total-body irradiation and bone marrow transplantation. Blood 1996; 87 (7): 3045-3052

33. Tauchmanovà L, Selleri C, De Rosa G, Esposito M, Orio F Jr, Palomba S, Bifulco G, Nappi C, Lombardi G, Rotoli B, Colao A. Gonadal status in reproductive age women after haematopoietic stem cell transplantation for haematological malignancies. Hum Reprod 2003; 18 (7): 1410-1416

34. Leader A, Lishner M, Michaeli J, Revel A. Fertility considerations and preservation in haemato-oncology patients undergoing treatment. Br J Haematol 2011; 153 (3): 291-308

35. Sklar CA, Constine LS. Chronic neuroendocrinological sequelae of radiation therapy. Int J Radiat Oncol Biol Phys 1995; 31 (5): 1113-1121

36. Stillman RJ, Schinfeld JS, Schiff I, Gelber RD, Greenberger J, Larson M, Jaffe N, Li FP. Ovarian failure in long-term survivors of childhood malignancy. Am J Obstet Gynecol $1981 ; 139$ (1): 62-66

37. Critchley HO, Wallace WH, Shalet SM, Mamtora H, Higginson J, Anderson DC. Abdominal irradiation in childhood; The potential for pregnancy. $\mathrm{Br} \mathrm{J}$ Obstet Gynaecol 1992; 99 (5): 392-394

38. Green DM, Peabody EM, Nan B, Peterson S, Kalapurakal JA, Breslow NE. Pregnancy outcome after treatment for Wilms tumor: A report from the National Wilms Tumor Study Group. J Clin Oncol 2002; 20 (10): 2506-2513

39. Chiarelli AM, Marrett LD, Darlington GA. Pregnancy outcomes in females after treatment for childhood cancer. Epidemiology 2000; 11 (2): 161-166

40. Norwitz ER, Stern HM, Grier H, Lee-Parritz A. Placenta percreta and uterine rupture associated with prior whole body radiation therapy. Obstet Gynecol 2001; 98 (5 Pt 2): 929-931

41. Holm K, Nysom K, Brocks V, Hertz H, Jacobsen N, Müller J. Ultrasound B-mode changes in the uterus and ovaries and Doppler changes in the uterus after total body irradiation and allogeneic bone marrow transplantation in childhood. Bone Marrow Transplant 1999; 23 (3): 259-263

42. Laursen EM, Holm K, Brocks V, Jarden M, Müller J. Doppler assessment of flow velocity in the uterine artery during pubertal maturation. Ultrasound Obstet Gynecol 1996; 8 (5): 341-345

43. Pridjian G, Rich NE, Montag AG. Pregnancy hemoperitoneum and placenta percreta in a patient with previous pelvic irradiation and ovarian failure. Am J Obstet Gynecol 1990; 162: 1205-1206 
44. Boice JD Jr, Tawn EJ, Winther JF, Donaldson SS, Green DM, Mertens AC, Mulvihill JJ, Olsen JH, Robison LL, Stovall M. Genetic effects of radiotherapy for childhood cancer. Health Phys 2003; 85 (1): 65-80

45. Schubert MA, Sullivan KM, Schubert MM, Nims J, Hansen M, Sanders JE, O'Quigley J, Witherspoon RP, Buckner CD, Storb R, Thomas ED. Gynecological abnormalities following allogeneic bone marrow transplantation. Bone Marrow Transplant 1990; 5 (6): 425-430

46. Kuwayama M. Highly efficient vitrification for cryopreservation of human oocytes and embryos: The Cryotop method. Theriogenology 2007; 67: 73-80

47. Stehlik E, Stehlik J, Katayama KP, Kuwayama M, Jambor V, Brohammer R, Kato O. Vitrification demonstrates significant improvement versus slow freezing of human blastocysts. Reprod Biomed Online 2005; 11 (1): 53-57

48. Peña JE, Chang PL, Chan LK, Zeitoun K, Thornton MH 2nd, Sauer MV. Supraphysiological estradiol levels do not affect oocyte and embryo quality in oocyte donation cycles. Hum Reprod 2002; 17 (1): 83-87

49. Azim AA, Costantini-Ferrando M, Oktay K. Safety of fertility preservation by ovarian stimulation with letrozole and gonadotropins in patients with breast cancer: A prospective controlled study. J Clin Oncol 2008; 26 (16): 2630-2635

50. Stern CJ, Toledo MG, Gook DA, Seymour JF. Fertility preservation in female oncology patients. Aust N Z J Obstet Gynaecol 2006; 46 (1): 15-23

51. Sanger WG, Olson JH, Sherman JK. Semen cryobanking for men with cancer criteria change. Fertil Steril 1992; 58: 1024-1027

52. Gandini L, Lombardo F, Salacone P, Paoli D, Anselmo AP, Culasso F, Dondero F, Lenzi A. Testicular cancer and Hodgkin's disease: Evaluation of semen quality. Hum Reprod 2003; 18 (4): 796-801

53. Opsahl MS, Fugger EF, Sherins RJ, SchulmanJD. Preservation of reproductive function before therapy for cancer: New options involving sperm and ovary cryopreservation. Cancer J Sci Am 1997; 3 (4): 189-191

54. Kuczyński W, Dhont M, Grygoruk C, Grochowski D, Wołczyński S, Szamatowicz M. The outcome of intracytoplasmic injection of fresh and cryopreserved ejaculated spermatozoa -- a prospective randomized study. Hum Reprod 2001; 16: 2109-2113

55. Bahadur G, Ling KL, Hart R, Ralph D, Riley V, Wafa R, Ashraf A, Jaman N, Oyede AW. Semen production in adolescent cancer patients. Hum Reprod 2002; 17 (10): 2654-2656

56. Braude P, Rowell P. Assisted conception. II--in vitro fertilisation and intracytoplasmic sperm injection. BMJ 2003; 327 (7419): 852-855

57. Shaw JM, Oranratnachai A, Trounson AO. Fundamental cryobiology of mammalian oocytes and ovarian tissue. Theriogenology 2000; 53: 59-72
58. Matson PL, Graefling J, Junk SM, Yovich JL, Edirisinghe WR. Cryopreservation of oocytes and embryos: Use of a mouse model to investigate effects upon zona hardness and formulate treatment strategies in an in-vitro fertilization program. Hum Reprod 1997; 12: 1550-1553

59. The Practice Committee of the American Society for Reproductive Medicine: Ovarian tissue and oocyte cryopreservation. Fertil Steril 2004; 82: 993-998

60. Oktay K, Cil AP, Bang H. Efficiency of oocyte cryopreservation: Meta-analysis. Fertil Steril 2006; 86: $70-80$

61. Kiran G, Kiran H, Coban YK, Guven AM, Yuksel M. Fresh autologous transplantation of ovarian cortical strips to the anterior abdominal wall at the pfannenstiel incision site. Fertil Steril 2004; 82: 954-956

62. Oktay K, Economos K, Kan M, Rucinski J, Veeck L, Rosenwaks Z. Endocrine function and oocyte retrieval after autologous transplantation of ovarian cortical strips to the forearm. JAMA 2001; 286: 1490-1493

63. Donnez J, Dolmans MM, Demylle D, Jadoul P, Pirard C, Squifflet J, Martinez-Madrid B, van Langendonckt A. Livebirth after orthotopic transplantation of cryopreserved ovarian tissue. Lancet 2004; 364 (9443): 1405-1410

64. Meirow D, Levron J, Eldar-Geva T, Hardan I, Fridman E, Zalel Y, Schiff E, Dor J. Pregnancy after transplantation of cryopreserved ovarian tissue in a patient with ovarian failure after chemotherapy. N Engl J Med 2005; 353 (3): 318-321

65. Oktem O, Urman B. Options of fertility preservation in female cancer patients. Obstet Gynecol Surv 2010; 65 (8): $531-542$

66. Oktay K, Newton H, Aubard Y, Sahla O, Gosden RG. Cryopreservation of immature human oocytes and ovarian tissue: An emerging technology? Fertil Steril 1998; 69: 1-7

67. Nisolle M, Casanas-Roux F, Qu J, Motta P, Donnez J. Histologic and ultrastructural evaluation of fresh and frozenthawed human ovarian xenografts in nude mice. Fertil Steril 2000; 74: 122-129

68. Curtin JP, Barakat RR, Hoskins WJ. Ovarian disease in women with breast cancer. Obstet Gynecol 1994; 84: 449452

69. Li CI, Anderson BO, Daling JR, Moe RE. Trends in incidence rates of invasive lobular and ductal breast carcinoma. JAMA 2003; 289: 1421-1424

70. Sonmezer M, Oktay K. Fertility preservation in young women undergoing breast cancer therapy. Oncologist 2006; 11: $422-434$

71. Gurgan T, Salman C, Demirol A. Pregnancy and assisted reproduction techniques in men and women after cancer treatment. Placenta 2008; 29: 152-159

72. Oktay K, Oktem O. Fertility preservation medicine: A new field in the care of young cancer survivors. Pediatr Blood Cancer 2009; 53 (2): 267-273 
73. Sonmezer M, Oktay K. Fertility preservation in female patients. Hum Reprod Update 2004; 10 (3): 251-266

74. Maltaris T, Koelbl H, Seufert R, Kiesewetter F, Beckmann MW, Mueller A, Dittrich R. Gonadal damage and options for fertility preservation in female and male cancer survivors. Asian J Androl 2006; 8: 515-533

75. Gabriel DA, Bernard SA, Lambert J, Croom RD 3rd. Oophoropexy and the management of Hodgkin's disease. A reevaluation of the risks and benefits. Arch Surg 1986; 121 (9): 1083-1085

76. Wo JY, Viswanathan AN. Impact of radiotherapy on fertility, pregnancy and neonatal outcomes in female cancer patients. Int J Radiat Oncol Biol Phys 2009; 73 (5): 1304-1312

77. Clowse ME, Behera MA, Anders CK, Copland S, Coffman CJ, Leppert PC, Bastian LA. Ovarian preservation by GnRH agonists during chemotherapy: A meta-analysis. J Womens Health (Larchmt) 2009; 18 (3): 311-319

78. Donnez J, Martinez-Madrid B, Jadoul P, Van Langendonckt A, DemylleD, Dolmans MM. Ovarian tissue cryopreservation and transplantation: A review. Hum Reprod Update 2006; 12: $519-535$

79. Snow M, Cox SL, Jenkin G, Trounson A, Shaw J. Generation of live young from xenografted mouse ovaries. Science 2002; 297 (5590): 2227

80. Chao L, Jiang AF, Deng XH, Yu HL, Zhen JH. Capability of oocyte maturation in human cryopreserved ovarian tissue following xenografting. Zhongguo Yi Xue Ke Xue Yuan Xue Bao 2008; 30 (5): 583-588
81. Cozzi E, Bosio E, Seveso M, Vadori M, Ancona E. Xenotransplantation-current status and future perspectives. Br Med Bull 2006; 75-76: 99-114

82. Pacey AA. Fertility issues in survivors from adolescent cancers. Cancer Treat Rev 2007; 33: 646-655

83. Tsai MC, Takeuchi T, Bedford JM, Reis MM, Rosenwaks Z, Palermo GD. Alternative sources of gametes: Reality or science fiction? Hum Reprod 2000; 15: 988-998

84. http://www.ttb.org.tr/mevzuat/index.php?option=com_con tent\&task=view\&id=741\&Itemid=33 (Accesed 1.09.2011)

85. Committee on Bioethics, American Academy of Pediatrics. Informed consent, parental permission, and assent in pediatric practice. Pediatrics 1995; 95 (2): 314-317

86. Moffa F, Biacchiardi CP, Fagioli F, Biasin E, Revelli A, Massobrio M, Madon E. Ovarian tissue cryostorage and grafting: An option to preserve fertility in pediatric patients with malignancies. Pediatr Hematol Oncol 2007; 24 (1): 29-44

87. Cohen CB. Ethical issues regarding fertility preservation in adolescents and children. Pediatr Blood Cancer. 2009; 53 (2): 249-253

88. Karpowicz P, Cohen CB, van der Kooy D. It is ethical to transplant human stem cells into nonhuman embryos. Nat Med 2004; 10 (4): 331-335 